\title{
Insulin, 70/30
}

National Cancer Institute

\section{Source}

National Cancer Institute. Insulin, 70/30. NCI Thesaurus. Code C29121.

A mixture of two types of insulin consisting of 70 percent long-acting insulin suspension and 30 percent rapid-acting insulin. Typically administered twice a day, insulin 70/30 controls postprandial glycemia and allows convenient mealtime dosing. The long-acting insulin component controls blood glucose levels between meals. Endogenous human insulin, a pancreatic hormone composed of two polypeptide chains, is important for the normal metabolism of carbohydrates, proteins and fats; it has anabolic effects on many types of tissues. ( $\mathrm{NClO4})$ 